\title{
Cezary Specht
}

prof. dr hab. inż.

Akademia Morska w Gdyni, Katedra Geodezji i Oceanografii

\section{Piotr Chrostowski}

dr inż.

Politechnika Gdańska, Katedra Transportu Szynowego i Mostów

\section{Pawel Dąbrowski}

mgr inż.

Akademia Morska w Gdyni, Katedra Geodezji i Oceanografii;

Wojewódzkie Biuro Geodezji i Terenów Rolnych w Gdańsku

\section{Jacek Szmagliński}

mgr inż.

Politechnika Gdańska, Katedra Transportu Szynowego i Mostów

\section{Mariusz Specht}

inż.

Akademia Morska w Gdyni, Katedra Geodezji i Oceanografii

\section{Marcin Dera}

inż.

Budimex S.A. w Gdańsku

\section{Wladysław Koc}

prof. dr hab. inż.

Politechnika Gdańska, Katedra Transportu Szynowego i Mostów

\section{Marcin Skóra}

mgr inż.

Akademia Marynarki Wojennej w Gdyni, Instytut Nawigacji i Hydrografii Morskiej

DOI: 10.35117/A_ENG_16_05_03

\section{Mobile satellite measurements on the Pomeranian Metropolitan Railway}

\begin{abstract}
This paper presents the process of organization and execution of the mobile satellite measurements conducted on the tracks of the Pomeranian Metropolitan Railway before officially entry the line into operation. These measurements allowed for the accurate identification of the actual geometric shape of the line. In the paper the issues of both design and construction phase of this railway line has been described. Moreover, the geodetic works during implementation of the investment has been introduced. The analysis of the surveying results was focused on the issues like transformation the measured data to the local system of coordinates called Gdańsk '70, repeatability of measurement's results and comparison of measured route with the designed geometrical layout.
\end{abstract}

Keywords: Railway track; Satellite measurements; Verification of horizontal coordinates 


\section{Introduction}

On May 1,1914, was put into operation a single-track railway line from Gdansk Wrzeszcz to Stara Pila station located on the line Pruszcz Gdansk - Kartuzy. This so-called "railway kokoszkowska" created the possibility of direct access from the Lower Terrace of Gdansk on Upland Kashubian. Due to the considerable slope, it was decided to refer to its operating locomotives TKt 2 used later also on mountain routes (among others Chabowka - Zakopane).

The history of this line was complicated [2]. After I World War crossed it border between the reborn Polish State and the Free City of Gdańsk. At the end of World War II were destroyed and have not been rebuilt. In 1994, Polish National Railways transferred to the State Treasury plots, through which ran discussed railway line. In 2003 sold land functioning for many years military training and the base CPN in Kielpnik was closed.

The XXI century began with intense local road investments in the region of Gdansk. This allowed for co-financing from EU funds. Work was carried out within the framework of the construction of the Slowackiego Route, Route Sucharskiego, Green Way, the southern bypass of Gdansk and route W-Z. Also invested in the public transport,among others the construction of new tram lines to Chelm, Łostowice and Piecki-Migowo, renovation of existing tracks and purchase of new rolling stock bus and tram. All of this was to increase the capacity of the road system and to encourage residents to use public transport. Not achieved in this area full of success and returned to the idea of using the reserve field of the liquidated railway line from Gdansk Wrzeszcz in the the TriCity Bypass.

\section{Construction of the Pomeranian Metropolitan Railway}

In 2007, the Center Scientific and Technical in Warsaw finished on behalf of PKP Polish Railway Lines S.A., with financial support from the Office of of Pomeranian Province Marshal (UMWP), the pre-feasibility study. After obtaining the PKP PLK has stated that it is not interested in the construction of a new railway line, which is why this task could be accomplished only by UMWP. The authorities of Gdansk, at first skeptical about the idea - in the conjunction with other plans building up the areas of a former railway, ultimately supported the actions of local provincial authorities. The project was included in the list of projects related to the UEFA European Football Championship organized in Poland in 2012.

In 2010, arised a special purpose company Pomeranian Metropolitan Railway S.A., whose task was to build a new railway line. A year later, on the basis of planning and development concept, feasibility of study and environmental analysis, the Pomeranian Region Management chose the final course of the new line. Also emerged in the tender contractor project documentation, which was Transprojekt Gdanski Sp. z o.o

Pomeranian Metropolitan Railway route can be divided into two parts. The first 10kilometer section, running by track liquidated after the war of Kokoszkowska Railway ,begins with a departure from the bus station E65 in the vicinity of the bus stop Fast Urban Railway Gdansk Zaspa and ends at the height of TriCity Bypass. At this point begins the second, newly designed section that goes from the old trace line to the north and extends up to the inclusion in the a railway line No. 201 in Rebiechowo.

The investment is divided into the following tasks:

- 1ab task: construction of a PKM on the section Airport - the inclusion of in the railway line 201 (investment financed by UMWP, led by the company PKM)

- task 1c: reconstruction of line 201 on the section of track breaker with a PKM trucks (investment PKP PLK S.A.)

- task 2: construction of the railway line section Airport - switching in station Gdańsk Wrzeszcz (investment UMWP, led by the company PKM) 
- reconstruction of the station Gdańsk Wrzeszcz in the framework of the modernization of the E-65 Warsaw - Gdynia (investment PKP PLK SA), made on the basis of a revised - on behalf of the company PKM - the reconstruction project of the station Gdańsk Wrzeszcz, in order to adjust the designed track system and platform screen door to the adoption of trains moving after a line PKM.

Finally line was not built for the tournament Euro 2012. Tender for general contractor of the entire line settled in March 2013, and contract for construction works with a consortium of Budimex S.A. \& Ferrovial Agroman signed on 05.07.2013 year. Consortium became responsible for the construction of PKM line within the task $1 \mathrm{ab}$ and tasks 2 .

Infrastructure line PKM characterized by using solutions never seen before on the Polish tracks, which are:

- attachment W14

- switchers arched R760,

- Compensatory instruments arc of the traverse up to $350 \mathrm{~mm}$,

- walls of the platforms with the step of facilitating the entrance of the track.

As part of the investment within two years built from scratch $18 \mathrm{~km}$ double track railway line and $1.3 \mathrm{~km}$ monorail liaison. On the route created 8 stops, most of which will act as local nodes of integration. Built 23 switchers, 5 of which are switchers with a radius of 1,200 meters to allow passage for the turning direction with speed of $100 \mathrm{~km} / \mathrm{h}$ and 2 are curved turnouts with movable beak frog (emergent in curving of based switcher Rz 12001 : 18.5). Lines of Pomeranian Metropolitan Railway were made as contactless rails 49E1 on prestressed concrete sleepers PS-93 with anchoring Vossloh W-14, of chipping ballast Class I of minimum thickness. $30 \mathrm{~cm}$. The protective layer of track is made of stone $0 / 31.5$ with a thickness of $15 \mathrm{~cm}$ and a layer of soil stabilized with cement $\mathrm{Rm}=1.5 \mathrm{MPa}$ with a thickness of min. $20 \mathrm{~cm}$. on 4 bridges rail surface made in the form of non ballasted track - rails anchoring Vossloh DFF21 [16] on molded "Wet" reinforced concrete blocks. The length of arcs with radii smaller than $\mathrm{R}=450 \mathrm{~m}$ and sections with high inclination located in the area of the braking and acceleration of trains was taken compaction substrates to the spacing of $55 \mathrm{~cm}$ and expanding prism of crushed stone to $55 \mathrm{~cm}$ from the front of the base on the outside of the curve.

Effective line construction speed is $120 \mathrm{~km} / \mathrm{h}$ for passenger trains and $80 \mathrm{~km} / \mathrm{h}$ for freight trains with local restrictions. In connection with the building of the line were created 4 new movement station (turnoff stations Brętowo and Kiełpinek, lateral station Firoga and station Gdańsk Rebiechowo) and 2 extreme stations (Gdańsk Wrzeszcz and Gdańsk Osowa) increased their coverage. 


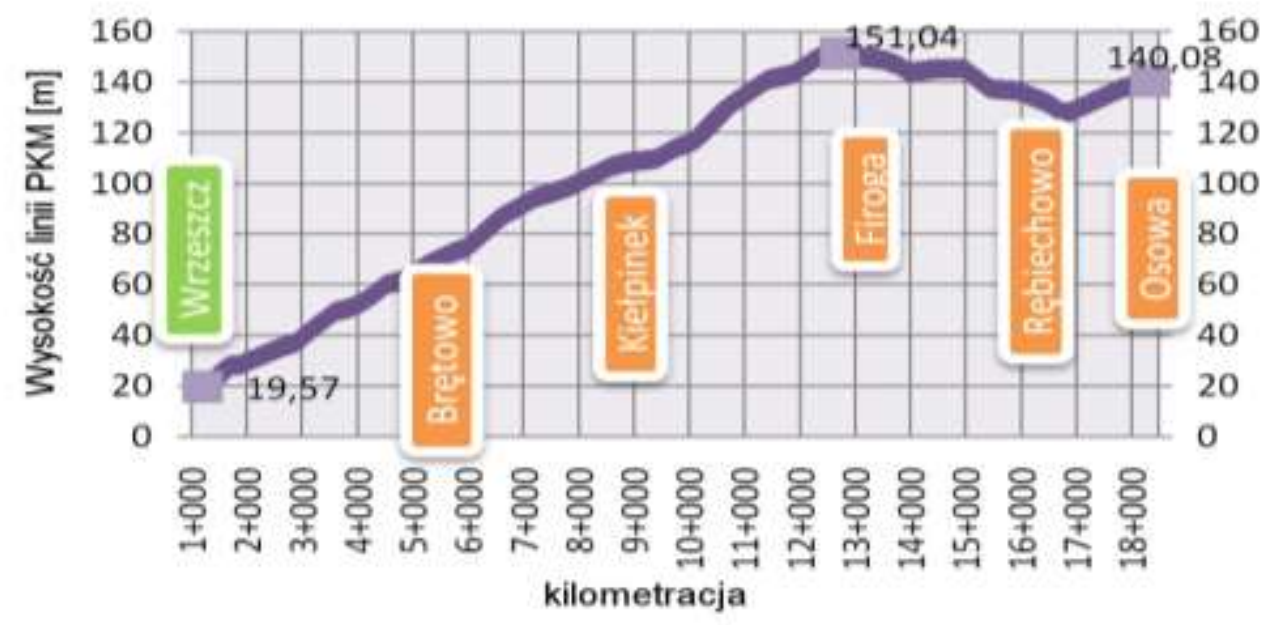

1. Longitudinal profile line PKM (given in meters above sea level)

It is worth noticing that the difference in levels between the lowest and highest point of the vertical alignment of tracks PKM is $131.47 \mathrm{~m}$ (Fig. 1). Translate to Medium ramps with values of $11.5 \%$. IN the Gdańsk Wrzeszcz - Firoga (about $12 \mathrm{~km}$.) There is a steady decline in the direction of decreasing mileage, And The biggest inclination longitudinal track of the values of $32 \%$ is in the region of entry lane No 2 for station Gdańsk Wrzeszcz. From the comments on the anticipated large traffic load, in the hold with a radius of $440 \mathrm{~m}$ at the entrance to make Wrzeszcz, in order to reduce noise emitted by the passing fleet and fuel rails, installed maintenance-free grease the rails by Railtech Papla.

In connection with the requirements of the EU directive line adjusted to the European Rail Traffic Management System (ERTMS) through the development of complementary wireless communication systems GSMR and traffic control system ETCS. ETCS infrastructure built on the line PKM is level 2, which will allow in the future for simultaneous movement $9 \div 12$ trains in each direction. Since the on duty traffic PKM were not equipped with the traditional Polish railway radio communication system - connectivity range FM frequency of $150 \mathrm{MHz}$, this causes some problems. For example, vehicles fitted with still rarely used in Poland telephony GSMR should not move the tracks PKM due to the inability to contact the duty of traffic.

\section{Geodetic works at the investment}

Geodetic works on the project Pomeranian Metropolitan Railway began in 2010. On behalf of the Pomeranian Regional Board of contractor was Provincial Office of Surveying and Agricultural Areas in Gdansk. In turn, the main contractor of construction work entrusted to force him surveying works a separate unit.

Range of mapping for design purposes covered the area of the planned investment with the collar about $30 \mathrm{~m}$. Because of the significant differences in the content of the basic map of the actual situation in the area decided to conduct a new measurement situation and altitude. Prepared documentation was one of the elements necessary for the preparation of the construction project.

Another important subject of preliminary work was to regulate the legal status of properties in the waist of the planned investment. Pomeranian Metropolitan Railway was one of the projects implemented for EURO 2012. Rules for the tournament, in particular the implementation of measures necessary for its execution are set out in the Act [15]. To this end, an inventory geodesic located in the immediate vicinity. 22 points were selected to 
measure the satellite, which are POK (basic warp Railway) [1]. It was found necessary to supplement and density of the network. They sought dots warp core indices, which were used in further stages as points of references. After drafting the network began to stabilize the control points. Almost all the points detailed horizontal geodetic been zastabilizowane two levels. As signs of underground concrete plates were used, and as the marks used ground concrete pillars with steel pin (pic. 2)

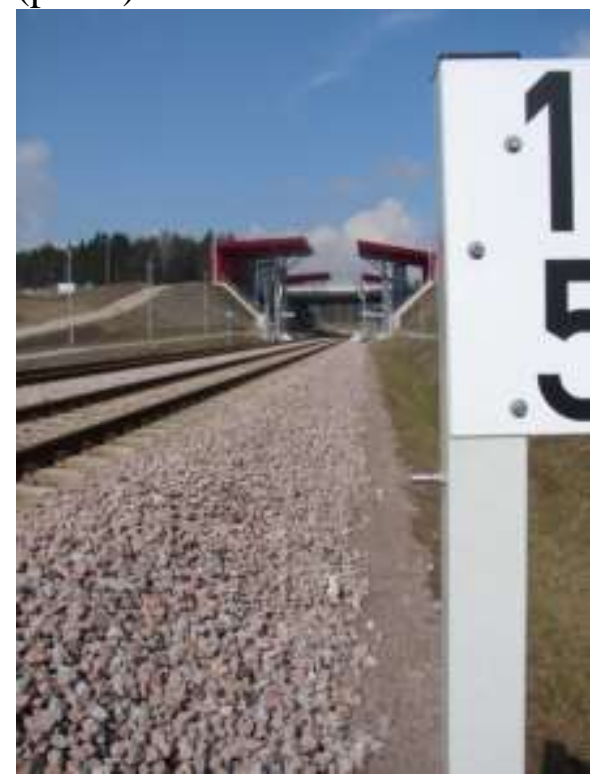

2. Sign of axis adjustment of the track Pomeranian Metropolitan Railway (photo by Pawel Dabrowski)

For the measurement was used dual-frequency GNSS receivers which in measurement hour sessions recorded satellite observations. The system ASG-EUPOS generated observations for virtual reference station. Downloaded data from the nearest physical reference station. After calculating the vectors were aligned network of the least squares method to yield Cartesian coordinates of the reference system WGS-84 [10]. The next step was the transformation of coordinates to the national spatial reference system in the form of flat rectangular coordinate system PL-2000 [9]. Points warp core base due to acquired coordinate system PL-2000 and in a local Gdańsk '70, served as points of alignment in the flat conformal transformation. Obtained mistakes of designation plane coordinates not exceeding $0.01 \mathrm{~m}$ in a PL-2000 and $0.04 \mathrm{~m}$ in a local Gdańsk '70. It assumes a total of 88 points detailed horizontal geodetic. In the immediate vicinity of the investment stabilized 28 benchmarks wall and earthen and led strings of precise geometric leveling. Measurement of altitude also covered most of the points the newly established detailed horizontal geodetic control network. Observation data-aligned method of least squares and a mean measurement errors not exceeding $2 \mathrm{~mm} / \mathrm{km}$. Warp horizontal and altitude were transferred to the contractor of construction work.

To inventory the rest of the old infrastructure was used technology of terrestrial laser scanning. The measurement involved a total of 15 objects: 5 railway viaducts, 1 road tunnel, 1 road viaduct, 3 footbridges and 5 passes under the tracks. For the measurement used pulse laser scanner Leica ScanStation C10. The measurement results compiled in the software Leica Cyclone. Voivodship conservator of monuments transferred prepared architectural documentation. Fig.ture 3 shows an example of photographic documentation containing the existing viaduct before the demolition and built in the same place a new object. 
Based on the realising warp was made surveying services of investments. After the completion of the construction work was carried out post-completion inventory measurement, the documentation of which it was necessary for the reception building.

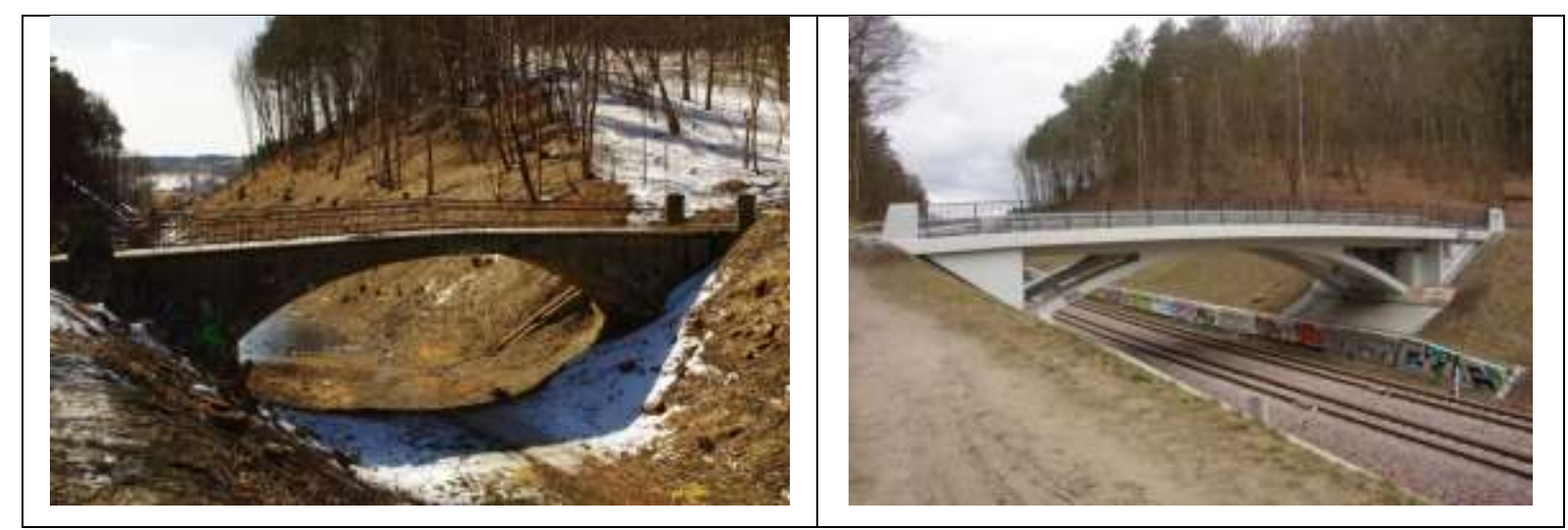

3. Demolished viaduct name of David Weiser (left) and newly built

footbridge in the area of street Gomółki in Gdansk Wrzeszcz (photo by Pawel Dabrowski)

New elements of the railway infrastructure, such as road and railway viaducts, bus stops, footbridges, etc Are covered by the duty of cyclic monitoring (control) their position. For this purpose, in the main walls are mounted benchmarks (steel pins) After the completion of the construction work has been made known measurement of zero, resulting in high accuracy designated coordinates of control points After indicated in the provisions period of time measurement is repeated The results of measurement are compared with the original. In this way they are referred to the settlement of individual components of buildings.

Under the decision of the Minister of Infrastructure and Development area of the Pomeranian Metropolitan Railway has been established closed. This term is defined in the Act [14] as a site of a trademark due to defense and national security. With the change in the status of the land was also associated need to create, separate from the district, Railway Documentation Centre of Geodesy and Cartography of the Pomeranian Metropolitan Railway (KODGiK PKM). Centre collects development and surveying materials appropriate for a reserved area.

\section{The organization and execution of satellite measurements on the lines of PKM}

The technique of mobile satellite measurements, developed since 2009 by an interdisciplinary team of scientists Technical University of Gdansk and Gdynia Maritime University, was presented among others in the works [3, 4, 11, 12, 13] .Pierwsze used the stocktaking measurements an polish active network of geodetic ASG-EUPOS . In the following solution we use dual-mode (GPS / Glonass), which proved to be appropriate and resulted in a significant increase in the availability of indicators adopted for the three levels of accuracy $(10 \mathrm{~cm}, 3 \mathrm{~cm}$ and $1 \mathrm{~cm})$.

But conducted in the years 2009-2014 measurements revealed the existence of barriers restricting the use of developed methodology for years. Its essential drawbacks include: an inability to increase the availability of assignments for the accuracy of the position coordinates of less than $1 \mathrm{~cm}$, obtaining an availability of over $90 \%$ for the measurement error of $3 \mathrm{~cm}$ seems to be impossible in practice, which includes the possibility of exceeding the availability of $50 \%$ of the calculation of the amount for the level $1 \mathrm{~cm}$. In this situation, the research team faced the necessity of seeking alternative methods of achieving measurements that would allow increasing the availability of highly accurate determinations GNSS referenced to the levels of $1 \mathrm{~cm}$ and $3 \mathrm{~cm}$. 
For this reason, the verification strategy has also conducted research. The new strategy was decided to rely on two elements:

- using a system of INS for positioning aid,

- using, in addition to GPS and Glonass systems, additional satellites Beidou system in the process of determining the position.

Carrying out the measurement of inventory Pomeranian Metropolitan Railway line enabled the company Budimex SA Used here for the first time aided inertial measurement system that allowed for at least a few seconds to maintain highly accurate position in case of a significant decline in the number of available satellites (eg. In built up or wooded).

On 10 and 26 June 2015, the band completed on the line two measurement campaigns. The first campaign (on 10 June 2015) made a team of four universities (Maritime Academy in Gdynia, Gdansk University of Technology, the Naval Academy in Gdynia and the University of Warmia and Mazury in Olsztyn) and the company Geotronics. Completed surveying inventory on the route Gdańsk airport - Gdańsk Wrzeszcz. In the measurements used 7 GNSS receivers (Trimble R10, the Leica GS15, Topcon Hiper Pro, Septentrio), whose appointment was supported systems inetrials. Further measurements - including the entire line PKMcompleted on 26 June 2015. (already without the participation of UWM Olsztyn). This time passing test was performed using two GNSS receivers Leica GS 15, and Trimble R10.

Acquired on June 26, 2015 (in 16.28 $\div 19.54$ hours) measurement data (fix rate of $20 \mathrm{~Hz}, 244$ 695 fixes) developed in accordance with the relevant procedures. Table 1 summarizes a summary of the results obtained.

Table 1. Values of selected parameters for the precision receivers NSS during the measurement campaign Gdańsk PKM 2015

\begin{tabular}{|c|c|c|c|c|c|c|}
\hline \multirow[t]{2}{*}{ Position parameter } & \multicolumn{3}{|c|}{ Without inetrial system } & \multicolumn{3}{|c|}{ With inetrial system } \\
\hline & 3D & 3D & 2D & 1D & $2 \mathrm{D}$ & 10 \\
\hline Systems & \multicolumn{3}{|c|}{ GPS / Glonass } & \multicolumn{3}{|c|}{ GPS / Glonass / Beidou } \\
\hline Area type & \multicolumn{3}{|c|}{ City 500.000 mieszkańców } & \multicolumn{3}{|c|}{ City 500.000 mieszkańców } \\
\hline MTBF for $U<1 \mathrm{~cm}$ & $2.06 \mathrm{~s}$ & $35.44 \mathrm{~s}$ & $7.183 \mathrm{~s}$ & $7.2 \mathrm{~s}$ & $75.93 \mathrm{~s}$ & $19.48 \mathrm{~s}$ \\
\hline $\begin{array}{ll}\text { Availability } & \text { for } \\
U<1 \mathrm{~cm} & \end{array}$ & $0.16 \%$ & $56.75 \%$ & $6.88 \%$ & $1.22 \%$ & $\begin{array}{l}88.03 \\
\%\end{array}$ & $\begin{array}{l}38.31 \\
\%\end{array}$ \\
\hline $\begin{array}{l}\text { Reliability for } U<1 \mathrm{~cm} \\
\text { and } \tau=300 \mathrm{~s}\end{array}$ & $\begin{array}{l}3.762 \times 10^{-} \\
4\end{array}$ & $52.15 \%$ & $4.53 \%$ & $0.80 \%$ & $\begin{array}{l}84.62 \\
\%\end{array}$ & $\begin{array}{l}32.85 \\
\%\end{array}$ \\
\hline $\begin{array}{l}\text { Continuity for } U<1 \mathrm{~cm} \\
\text { and } \tau=300 \mathrm{~s}\end{array}$ & $23.36 \%$ & $91.88 \%$ & $65.86 \%$ & $\begin{array}{l}65.92 \\
\%\end{array}$ & $96.12 \%$ & $\begin{array}{l}85.73 \\
\%\end{array}$ \\
\hline MTBF for $U<3 \mathrm{~cm}$ & $134.90 \mathrm{~s}$ & $\begin{array}{l}1.422 \times 10^{3} \\
\mathrm{~s}\end{array}$ & $202.12 \mathrm{~s}$ & $\begin{array}{l}226.89 \\
\mathrm{~s}\end{array}$ & $\begin{array}{l}\text { All } \\
\text { time }\end{array}$ & $\begin{array}{l}357.11 \\
\mathrm{~s}\end{array}$ \\
\hline $\begin{array}{ll}\text { Availability } & \text { for } \\
U<3 \mathrm{~cm} & \\
\end{array}$ & $76.52 \%$ & $83.15 \%$ & $79.97 \%$ & $\begin{array}{l}98.29 \\
\%\end{array}$ & $100 \%$ & $\begin{array}{l}99.49 \\
\%\end{array}$ \\
\hline $\begin{array}{l}\text { Reliability for } U<3 \mathrm{~cm} \\
\text { and } \tau=300 \mathrm{~s}\end{array}$ & $74.83 \%$ & $82.97 \%$ & $78.30 \%$ & $\begin{array}{l}97.00 \\
\%\end{array}$ & $100 \%$ & $\begin{array}{l}98.65 \\
\%\end{array}$ \\
\hline $\begin{array}{l}\text { Continuity for } U<3 \mathrm{~cm} \\
\text { and } \tau=300 \mathrm{~s}\end{array}$ & $97.80 \%$ & $99.78 \%$ & $98.52 \%$ & $\begin{array}{l}98.68 \\
\%\end{array}$ & $100 \%$ & $\begin{array}{l}99.16 \\
\%\end{array}$ \\
\hline MTBF for $U<10 \mathrm{~cm}$ & $3.235 \times 10^{3}$ & $\begin{array}{l}4.859 \times 10^{3} \\
\mathrm{~S}\end{array}$ & $2.333 \times 10^{3}$ & $\begin{array}{l}\text { All } \\
\text { time }\end{array}$ & $\begin{array}{l}\text { All } \\
\text { time }\end{array}$ & $\begin{array}{l}\text { All } \\
\text { time }\end{array}$ \\
\hline Availability & $84.62 \%$ & $85.39 \%$ & $84.86 \%$ & $100 \%$ & $100 \%$ & $100 \%$ \\
\hline
\end{tabular}




\begin{tabular}{|l|l|l|l|l|l|l|}
\hline$U<10 \mathrm{~cm}$ & & & & & \\
\hline $\begin{array}{l}\text { Reliability for } \\
U<10 \mathrm{~cm} \text { and } \tau=300 \mathrm{~s}\end{array}$ & $84.54 \%$ & $85.34 \%$ & $84.47 \%$ & $100 \%$ & $100 \%$ & $100 \%$ \\
\hline $\begin{array}{l}\text { Continuity for } \\
U<10 \mathrm{~cm} \text { and } \tau=300 \mathrm{~s}\end{array}$ & $99.90 \%$ & $99.93 \%$ & $99.87 \%$ & $100 \%$ & $100 \%$ & $100 \%$ \\
\hline
\end{tabular}

Analyzing the results of the research, it was found that the use of a receiver with power INS system and increasing the number of available satellites has increased the accessibility for all three levels of accuracy. Can basically conclude that all three measures (availability, reliability and continuity) for levels $3 \mathrm{~cm}$ and $100 \mathrm{~cm}$ are close to $100 \%$. While the level $1 \mathrm{~cm}$ increase availability in the horizontal plane is very high $(31.28 \%)$, as is the increasing availability in the vertical plane (1D) $-31.34 \%$. There is no doubt that the team led by a number of years, studies have the prospect of continuing to increase the accuracy obtained.

\section{Preliminary analysis of the research results}

Section analyzed is $3.5 \mathrm{~km}$ long and $900 \mathrm{~m}$ long runs after the flyover along the Gdansk Airport. At length of the viaduct is located passenger stop Gdańsk Airport on platforms in the form cantilevered plates anchored to the plate object. Overpass is laid surface unballasted. From km $15+050$ line runs on an embankment, and the tracks are made as a classic macadam. In $\mathrm{km} 15+500$ starts Gdańsk Rębiechowo station at which the $\mathrm{km} 16+450$ diverges from the track \# 2 switchboard single path, which is a line number 253 . $\mathrm{km} 16+500$ begins the long arch cant of $150 \mathrm{~mm}$, which outputs a line to north towards the station Gdańsk Osowa. Rays arcs are as follows: $499.35 \mathrm{~m}, 2,024.8 \mathrm{~m}, 1000 \mathrm{~m}$ and $640 \mathrm{~m}$.

\section{The transformation of measured points of the Gdańsk '70}

Pomeranian Metropolitan Railway project has been made on the maps for designing in a local Gdańsk '70. Whereas in the result of measurements of the satellite coordinates built track line RMC are set out in the national spatial reference system with the mapping of the ellipsoid WGS 84. To be able to compare design coordinates with the measurement results, it was necessary to transform data points to the local Gdańsk '70.

To transform the coordinates of the points of measurement software was used C-GEO [6]. For the purpose of this work was carried out first performed an analysis of the accuracy of the C-GEO transition without a matching points. Uses geodetic control points with known system of coordinates Gdańsk '70, which was conducted static GNSS measurements to determine their coordinates in 2000. As it turned out, the differences between the coordinates of the same points designated by measuring and calculated as a result of the transformation are significant and there is, in extreme cases up to $67 \mathrm{~mm}$.

For this reason it was decided to perform a transformation on the basis of matching points located along the PKM. These points were once used for the same purpose - during the transition to the Gdańsk '70 rail warp core created for the implementation of PKM. They represent points of geodetic control network of well-known system of coordinates Gdańsk '70, passed the construction contractor PKM by the contracting authority. At these points were made static GNSS observations and set their coordinates in a 2000 achieved greater accuracy than the transformation of the transformation without adjustment points - in the worst case the error of transformation was $4 \mathrm{~cm}$. The use of transition points can therefore adapt to improve the situation, assuming that the transformed points are located in the vicinity of matching points. By using the procedures outlined in the C-GEO to the Gdańsk '70 were all transformed (ie. Approximately 205,000) measuring points. 


\section{Rating repeatability of measurements}

Repeated measurement analysis was performed on sections which were measured twice. The adopted method is representative of the graph indicator of the difference between the systems: pomierzonym and designed, obtained in the measurement of A and B measurements for each of the tracks. These differences were determined using Bentley Power Rail Track [5], in which the system was designed geometric lines PKM. Comparative analysis proceeded in the following stages:

- the introduction of satellite-measured points of the track to the Power Rail Track (after transform their coordinates to the Gdańsk '70)

- the establishment of a broken line connecting the measuring points, - calculate the distance between the broken line created and designed in a geometric arrangement Gdańsk '70 (with the assumed 5-foot step).

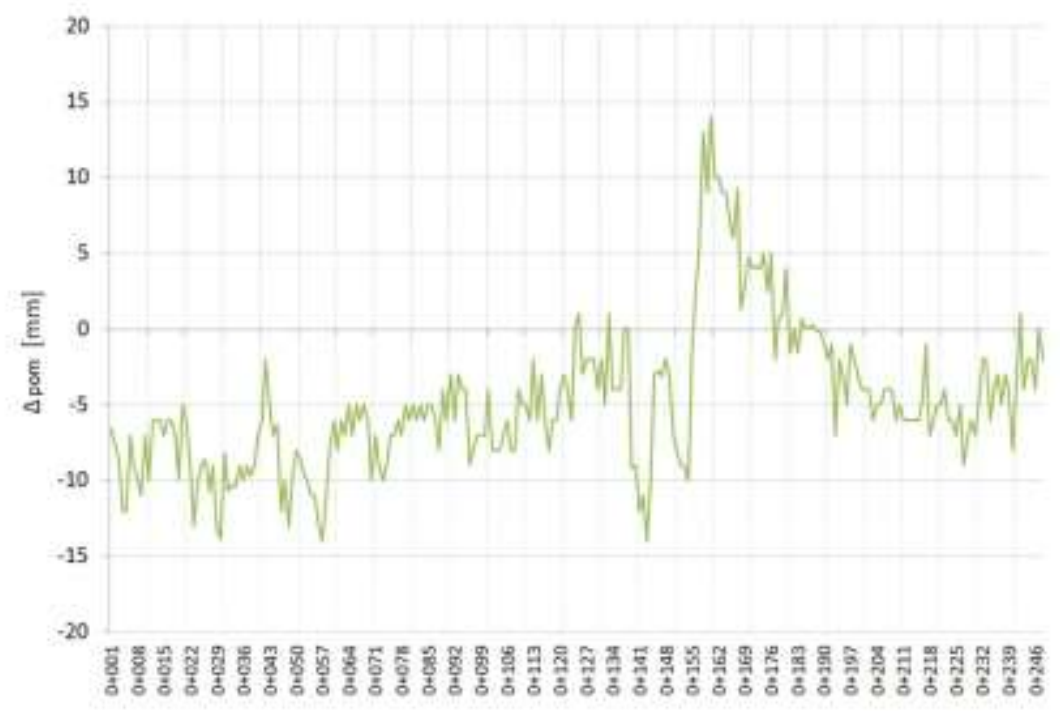

Kilometracja

4. Analysis of the repeatability for track No. 1

The determined distances are referred to hereinafter as "shifts". Indicator of the difference between the offsets measurements A and B, marked as $\square$ pom. In the case of track No. 1 (Fig. 4) shows that $\square$ pom rate fluctuates around $10 \mathrm{~mm}$, only on the sections $\mathrm{km} 16+$ $500 \div 16+700$ and $\mathrm{km} 17+100$ to $17+250$ falls. In the first of these locations path runs along the aperture field in the form of so-called. "Green screen", while the second is located in the arch of a very large and cant in a deep trench - all these elements result in a reduction of the visible height Topocentric. In both cases, the ratio decreased $\square$ pom is associated with a reduction in the number of satellites observed due to the aperture field. A significant impact on the trajectory may also have the conduct of trucks with antennas - during the passage of the measuring antennas A carts were pushed by the trolley, while during the measurement B drawn. As stated, the same remarks also apply to the situation in track \# 2.

\section{Comparison of the measured routing of the planned course}

Analyzed the following test rides: 
- A measurement of track No. 1 on the section $\mathrm{km} 14+120$ to $17+650$,

- measurement of B track No. 1 on the section $\mathrm{km} 16+240$ to $17+650$

- A measurement and the measurement of B track No. 2 on the section km $14+130$ to $17+$ 670.

Just as in section 5.3, evaluated the differences between the broken line connecting measurement points designed a system exponentially.

In order to eliminate from the analysis of measured points with less accuracy - that could interfere with the results of the analysis - it was introduced two-step mechanism for evaluating the quality of the data and their possible correction. In the measurement of a track No. 1 averaging measurements inaccurate concerned the 61 points of a total of 717 . It can be concluded that $10 \%$ of the points were measured with much less accuracy than the other.

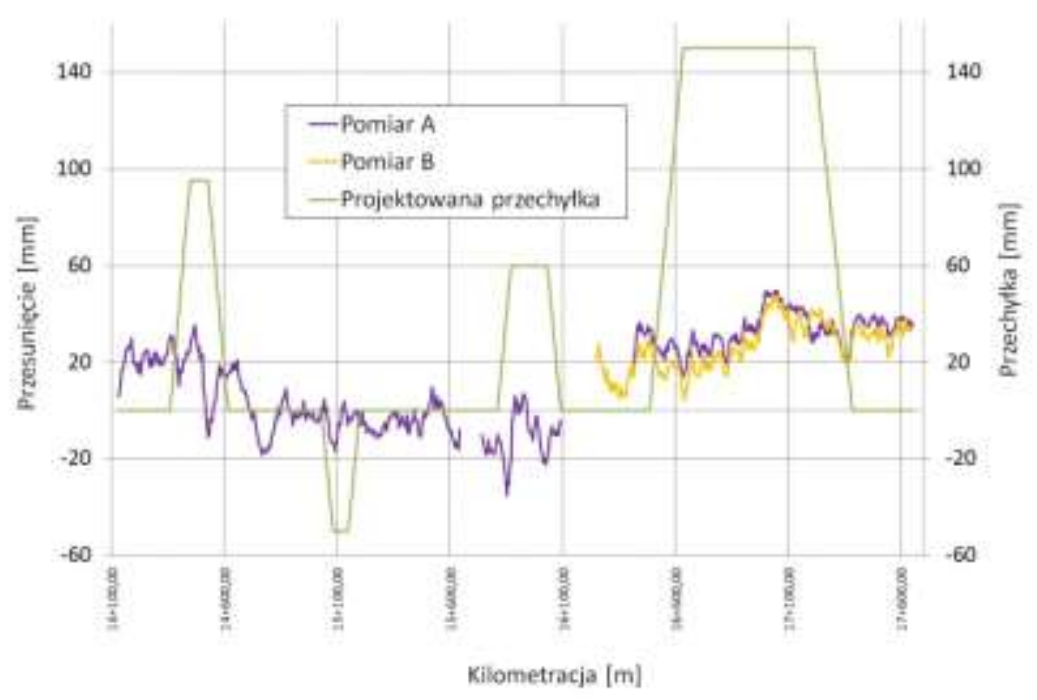

5. Graphs of shifts for track No. 1

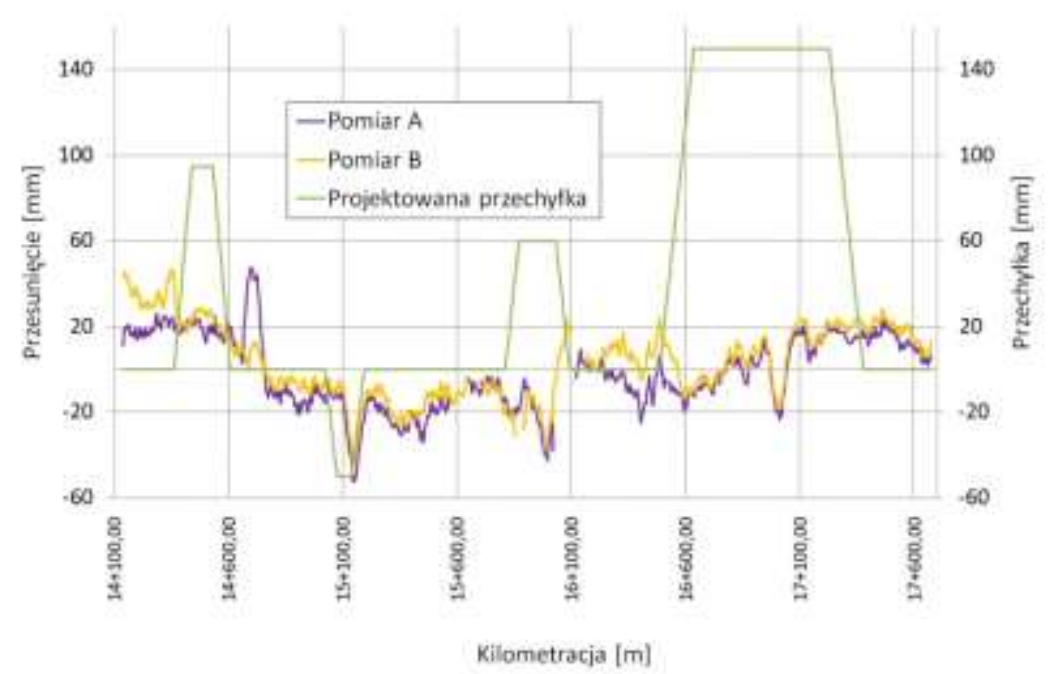




\section{Graphs of shifts for track No. 2}

As is apparent from pictures 5 and 6 , the shift values reach certain values, regardless of the shape of path (straight line / arc) and vary in certain ranges for both tracks. The exception is the last arc canted equal to $150 \mathrm{~mm}$, where the track No. 1 observe the highest average value of the offset. The causes of this situation may be a few. One is that the curves with a large cant of the track axis is offset inwardly by an amount resulting from the cant. During the conquest of such arches are having difficulty launching the track outside the arc without lifting due to the high resistance of the ballast beneath the surface of the base.

Assess the regularity of track position also disturbed the errors of measurement coordinate transformations from the 2000 to the local Gdańsk '70. These errors are diverse, as related to a specific fit point, each of which is burdened with another error to determine position. This problem will not apply to future investments longer, due to the introduction of Ministerial Decree [9] obligation to apply the national national spatial reference system for mapping at scales larger than 1: 10,000. In the case of PKM regulation is not yet in force.

The last factor generating the error is accepted measurement technique. In some configurations plane of the antenna with respect to the horizon (high inclination of the longitudinal arch with a large tilt) is limited by the ability to track the satellites of a small height Topocentric that enable accurate positioning [10]. In addition, the curves located in the trenches there is a problem diaphragms field, which may result in a decrease in accuracy.

\section{Summary}

Mobile satellite measurements conducted on the lines of the Pomeranian Metropolitan Railway before officially putting it into operation, enabled the accurate reproduction of the actual shape. This was so important that the design of this line was made on the maps for designing in a local Gdańsk '70, and stabilization characters axis adjustment of the track and then shaping the geometric lines took place in the adaptation of the State spatial reference system.

To be able to compare design coordinates with the results of the measurements, it was necessary to transform data points to the local Gdańsk '70. In the specific case used transformation on the basis of matching points located along the PKM using software C-GEO.

Analyzed section of the PKM $3.5 \mathrm{~km}$ long, runs along the Gdansk Airport. It was found that the repeatability of the measurement fluctuates around $10 \mathrm{~mm}$. Occurring locally decrease repeatability is probably due to a lower number of satellites being tracked. Also points to the significant influence the conduct of trucks with antennas on a trajectory - during the passage of the measuring antennas A carts were pushed by the trolley, while during the measurement B drawn.

In order to compare the measured routing the course of the projected drawn graphs of measured differences in elevation and elevation of design for individual measurements. The analysis of the graphs clearly show that these differences, both on curves and straight sections, averages $20 \mathrm{~mm}$; the exception is canted arch of $150 \mathrm{~mm}$, where the differences reach a level of $30 \mathrm{~mm}$. Comparative analysis of the alignment line PKM terms designed geometric arrangement of the selected episode showed high compliance. It should be noted that detected an error - at $20 \mathrm{~mm}$ - also contains a component resulting from the methods of measurement and coordinate transformations to the Gdańsk ' 70.

\section{Source materials}


[1] Dera M., Widerski T. Osnowy kolejowe oraz prace geodezyjne podczas modernizacji i budowy linii kolejowych. Geodezja inżynieryjna - Obsługa geodezyjna inwestycji i pomiary przemieszczeń, Archiwum Geomatyki, Gdańsk 2014, s. 143-171.

[2] Koc W., Lewiński L. Historia linii kolejowej Wrzeszcz - Kokoszki. (Materiały poseminaryjne - edycja polska) International Seminar - European Workshop "Preservation of the Industrial Heritage - Gdańsk Outlook", Gdańsk, 11-14 May 1993, s. 73-80.

[3] Koc W., Specht C. Application of the Polish active GNSS geodetic network for surveying and design of the railroad. First International Conference on Road and Rail Infrastructure - CETRA 2010, Opatija, Croatia, 2010, s. 757-762.

[4] Koc W., Specht C., Nowak A., Jurkowska A., Chrostowski P., Lewiński L., Bornowski M. Wstępne wyniki badań dostępności sieci ASG-EUPOS podczas inwentaryzacji trasy kolejowej KOŚCIERZYNA - KARTUZY. Archiwum Fotogrametrii, Kartografii i Teledetekcji, tom 19, 2009, s. 193-200.

[5] Oprogramowanie Bentley Rail Track, https://www.bentley.com/en/products/productline/civil-design-software/power-rail-track [dostęp 22.03.2016]

[6] Program C-GEO dla Windows 2016, http://softline.xgeo.pl/index.php/c-geo [dostęp 22.02.2016 r.]

[7] Projekt wykonawczy Pomorska Kolej Metropolitalna, Tom II - Roboty Torowe. Transprojekt Gdańsk Sp. z o.o., Gdańsk 2011.

[8] Rozporządzenie Ministra Administracji i Cyfryzacji z dnia 12 lutego 2013 r. w sprawie bazy danych geodezyjnej ewidencji sieci uzbrojenia terenu, bazy danych obiektów topograficznych oraz mapy zasadniczej (Dz. U. z 2013 r. Nr 0, poz. 383).

[9] Rozporządzenie Rady Ministrów z dnia 15 października 2012 r. W sprawie państwowego systemu odniesień przestrzennych (Dz.U. 2012 poz. 1247).

[10] Specht C. System GPS. Wydawnictwo BERNARDINUM, Pelplin 2007.

[11] Specht C., Koc W., Chrostowski P., Szmagliński J. Satellite inventory of tram track geometrical layout. [CD-ROM] Conference Papers of 13th International Conference \& Exhibition RAILWAY ENGINEERING 2015, Edinburgh, Scotland, 2015, Metros \& Tramways Section.

[12] Specht C., Koc W., Smolarek L., Grządziela A., Szmagliński J., Specht M. Diagnostics of the tram track shape with the use of the global positioning satellite systems (GPS/Glonass) measurements with a $20 \mathrm{~Hz}$ frequency sampling. Journal of Vibroengineering 2014, vol. 16, iss. 6, 3076-3085.

[13] Specht C., Nowak A., Koc W., Jurkowska A. Application of the Polish Active Geodetic Network for railway track determination. Transport Systems and Processes - Marine Navigation and Safety of Sea Transportation, CRC Press - Taylor \& Francis Group 2011, London, UK, s. 77-81.

[14] Ustawa z dnia 17 maja 1989 r. Prawo geodezyjne i kartograficzne. Dz. U. z 2015 r., nr 0 , poz. $520 \mathrm{z}$ późn. zm.

[15] Ustawa $z$ dnia 7 września 2007 r. o przygotowaniu finałowego turnieju Mistrzostw Europy w Piłce Nożnej UEFA EURO 2012. Dz. U. z 2007 roku, nr 173, poz. 1219.

[16] Vossloh AG, www.vossloh-fastening-systems.com [dostęp 22.03.2016 r.] 